\title{
RETHINKING THE SIGNIFICANCE OF PESANTREN-BASED INTEGRATIVE ISLAMIC STUDIES IN THE FACULTY OF USHULUDDIN AND DAKWAH STATE INSTITUTE OF ISLAMIC STUDIES KEDIRI
}

\author{
Moh. Asror Yusuf \\ State Institute of Islamic Studies Kediri, Indonesia \\ E-mail: asroryusuf@iainkediri.ac.id
}

\begin{abstract}
The Faculty of Ushuluddin and Dakwah State Institute of Islamic Studies Kediri is facing many challenges, one of which is related to the number of students, as it currently seems to be less interesting and irrelevant to the work field. Moreover, the Islamic Studies provided seems to be supplying insufficient capability for graduates compared with the pesantren alumni. Based on this statement, this paper seeks to find some proper solutions to suggest. This study examined the documents of this faculty, specifically related to the curriculum, and also interviewed the stakeholders. It was concluded that to maintain and develop the faculty's existence, some changes were necessary. These solutions include strengthening the integration within Islamic studies by using a practical theology approach in teaching and learning, as well as continuously developing the ability of students to attain a higher order of thinking. The third solution was to give special attention to the pesantren-based primary Islamic literature, which was mostly delivered in Arabic, along with strengthening the students' ability in understanding the language.
\end{abstract}

Keywords: Islamic studies; integration; pesantren.

\section{Introduction}

Examining Islamic teachings is an obligation for each of its adherents. The goal is nothing but for every Muslim to have religious knowledge as a provision to enforce God's commandments and avoid His prohibitions. Abū Hāmid al-Ghazālī classified sciences into two categories, namely: religious science (al-ulum al-diniyah) and intellectual science (al-ulum al-'aqliyah). Religious science consists of tawhid (theology), fiqh, and akbläq and sufism, whose primary basis is a 
revelation. These sciences study the divine oneness ( $\mathrm{ilm}$ al-tawhid), prophetic, the afterlife, the Qur'ān, the Hadīth, ijmā', and qiyass, studying about worship and akblàq (good character, virtue, and morality). From this scope of the study, these sciences discuss not only the doctrinal basis of Islam but also encompasses religious practices at once. Meanwhile, intellectual science consists of natural, social, and other discourses derived from human thought process (reasoning) or empirical experiences such as medicine, geometry, astronomy, music, physic, and other related science. From the perspective of fiqh or Islamic jurisprudence, al-Ghazāin argued that studying religious science is fard 'ayn (heavily obligated) while studying intellectual science is fard kifäyah (obligation with no strict demand). ${ }^{1}$

Based on the historical records, Islamic studies during its development were not only conducted by Muslims, but also many non-Muslim figures took part in this field. It happened up to this day with a broader scope of the study, ranging from revelation text and the beliefs to religious practices of Muslim society.

In non-Arab foreign universities such as United Kingdom, France, Germany, the Netherlands, the United States, and Australia, Islamic Studies grew rapidly, particularly since 2001. This development is perhaps indicated by the increasing attention of the society on the Muslim community in each country. This was signed by the increasing number of students enthusiastic, the emergence of new courses and study centres in this field. The concrete example of these, among others, are; (1) the establishment of interdisciplinary and trans-regional study centres on Islamic and Muslim studies in the modern world; (2) the increasing number of scholars working on collaborative research and inter-university student/lecturer exchange program; (3) the establishment of the training program for local Muslim leader training and the similar program specifically held at colleges; and (4) the development of Islamic studies learning models. ${ }^{2}$

In the last two decades, the model and approach in studying Islam, especially in universities, have developed rapidly, including in the universities under Islamic religious colleges (Pendidikan Tinggi

1 Osman Bakar, Hierarki Ilmu: Membangun Rangka Pikir Islamisasi Ilmu, terj. Purwanto (Bandung: Mizan, 1992), 179-247.

2 A Report to HEFCE, International Approaches to Islamic Studies in Higher Education, Subject Centre for Languages, Linguistics and Area Studies, Subject Centre for Philosophical and Religious Studies, June 2008. 
Keagamaan Islam; PTKI) in Indonesia. Within PTKI, Islamic Studies is not only learned by using textual approaches, but it also complemented with social, anthropology, and many other approaches. According to the Regulation of Minister of Religion (PMA) Republic of Indonesia No. 33 the Year 2016 on the academic degree of Religious College, it can be known that Islamic studies are under Faculty of Ushuluddin which consists of major study programs as follows: (1) Qur'ānic Science and Exegeses (Tafsir), (2) Science of Hadith, (3) Theology and Islamic Philosophy, (4) Religious Studies, and (6) Sufism and Psychotherapy.

In particular, in IAIN Kediri (literally means State Institute of Islamic Studies Kediri), the Faculty of Ushuluddin was merged with the Faculty of Dakwah - following the Regulation of Minister of Religion of the Republic of Indonesia No. 32 the Year 2018-which its name then became the Faculty of Ushuluddin and Dakwah. In this regards, the faculty, however, organizes major study programs under both scopes; those are (1) Qur'ānic Science and Exegeses, (2) Science of Hadīth, (3) Religious Studies or Comparative Religion, (4) Sufism and Psychotherapy, (5) Islamic Communication and Broadcasting, (6) Islamic Psychology, and (7) Sociology of Religion. In its history, while it was still a branch faculty of IAIN Sunan Ampel Surabaya, the faculty of Ushuluddin (IAIN Kediri) has organized the study program of Comparative Religion, then followed by the establishment of the Tafsir Hadis. After the advent of autonomy policies and transforming to be STAIN Kediri (Public Islamic College) in 1997, the Faculty of Ushuluddin further organized some additional study programs, totally as mentioned above.

In terms of quantity, specifically seeing from the newly registered student, the Faculty of Ushuluddin frequently gets fewer enthusiasts comparing with other faculties, for example, the Faculty of Tarbiyah (Islamic Education) or the Faculty of Economy. The low attention has occurred for a long period and gradually spawned the perception that there are not many prospective students interested in the Faculty of Ushuluddin and Dakwah. This perception perhaps is emerged because of the presence of work field-related considerations after graduation from both prospective students and parents in selecting a study program. Because of this, the work-oriented majors or whose job field identification is clear then relatively has many enthusiasts. 
In addition to the challenges of studying at the college for work orientation, Islamic studies in the Faculty of Ushuluddin and the Faculty of Dakwah currently also face many other challenges. Those challenges are as follows. First, there is an assumption that graduates are less able to compete with alumni of pesantren in proselytizing in the community. The alumnus of the Faculty of Ushuluddin and Dakwah mostly is considered as not well-prepared yet to become religious figures or preachers in society. Thus, some people are still unsure of the depth of their religious knowledge.

Second, the intellectualization of Islamic studies was not accompanied by strong efforts to increase the religious commitment of its students, so the mission of proselytizing religious-educational institutions seemed to be unclear. Some people even suspect this attempt at intellectualization may decrease the degrees of students' faith, but this assumption remains to be carefully more reviewed. Hartono Ahmad Jaiz sees that under the IAIN environment, there has been a digression of Islamic teachings or even deviation. In addition, the PTKI curriculum is seen as no longer consisting of Islamic nuance and emphasize more on socio-historical aspects. This assumption is built based on the local subject allocation, which tends to emphasize on socio-historical approach, totally up to $43 \%$, and consequently to reduce the local Islamic subject that should be more deeply studied. ${ }^{3}$

Third, the decline of moral or good character of the student indicates that Islamic studies were unsuccessful in character building. Meanwhile, the Indonesian government, through educational policy planning and curriculum, directed to adopt value-based education, namely character education (pendidikan karakter). Hence, the reality is certainly contradicted with the efforts of the government in realizing character education, since at the elementary, middle, until college levels, as a response to moral decadence and the growing mental crisis in society.

It is clear that in facing those challenges, the idealism of the founding fathers indeed should be maintained along with the effort to develop and contextualize to provide relevant education in the faculty with the work affairs. Therefore, improvisation is necessarily needed in the Faculty of Ushuluddin and Dakwah that it can get attention and appreciation from the stakeholders and the public society. In this

${ }^{3}$ Hartono Ahmad Jaiz, Ada Pemurtadan di IAIN (Jakarta: Pustaka al-Kautsar, 2004). 
context, I argue that this problem is important to be discussed more deeply.

Based on the background above, this study attempts to analyze the existing or actual conditions of the Faculty of Ushuluddin and Dakwah of IAIN Kediri, the desires and expectations of stakeholders, and to find the excellence as a hallmark that can be connected to the working world.

There are several previous works under a similar topic and one of those was conducted by Machasin and his team, which focused on produced policy within colleges, ${ }^{4}$ specifically STAIN in Central Java. In their work, they involved faculty members, including the officials, students, employees, and graduates. The analytical techniques used are exploratory descriptive, with stakeholder perspectives, administrative and financial officials, teaching-learning processes, work ethos, culture, and good governance. The finding shows that there are differences in implementation, while from the perspective of administrative and financial managers, they are facing a similar problem that is the less optimal of department units in serving the produced policy, hence it affects the index performance of the faculty.

On the other hand, this study used a qualitative approach that would produce descriptive data on spoken as well as written words and observable behaviour. To make it narrow and focus, this study takes the Faculty of Ushuluddin dan Dakwah of IAIN Kediri of East Java as the object of the research. In terms of the source of the data, it is derived from documents related to the faculty and the exposure of its faculty members. Sampling is taken purposively according to the needs of the data and is collected through documentation, interviews, observations, as well as library reviews. Meanwhile, the validity of the data is monitored by the triangulation method.

\section{The Dynamics of Approach in Islamic Studies at Islamic Universities in Indonesia}

Islamic studies in Indonesia, mainly in the universities under PTKI, has been influenced by many disciplines, either interdisciplinary or multidisciplinary, and enriched by various approaches, not only normative but also rational-contextual. It was much developed comparing with its early period of development,

\footnotetext{
4 Machasin dkk, "Strategi Peningkatan Mutu Perguruan Tinggi Agama Islam Berbasis Balanced Scorecard," Walisongo, Vol. 19, No. 2 (2011), 483-509.
} 
which was dominated by normative doctrinal approaches. At that time, Islamic teaching such as figh (the Islamic jurisprudence) sharia and theology (kalam) was taught to students through a normative approach and indoctrination model. Consequently, it triggered the emergence of a heavy scriptural Islamic studies tendency, meaning pointed out a narrow field like religious practices of worship and theological discussion. According to Azyumardi Azra-as quoted by Ni'am-this phenomenon was caused by the dominance of the normative-idealistic approach developed in several Middle Eastern Islamic colleges, primarily al-Azhar University in Egypt. Even more severely, it tended to focus on a single school of thought (mazhab), whereas Islam has many others. Ironically, the motivation of its tendency was the anxiety that students would mislead in understanding Islam and harmful for their faith. ${ }^{5}$ Perhaps, the concern was influenced by the traditionalist group's view in which the earlier Islamic scholars' products were considered to be complete and final. Yet the traditionalist scholar's methods commonly consisted of excessive fanaticism towards each of the adhered school of thought. ${ }^{6}$

Nevertheless, in the 1970s era, there were mushrooming of renewal of Islamic thought discourse. M. Amin Abdullah stated that Islamic higher education in Indonesia gradually developed the model of Islamic studies approach into three models. Those are periodically described as follows; first, in 1950-1970 or called the period Ulum alDin, second, in 1970-1990 or called the al-Fiker al-Islammi period, and third, in 1921-2011 or Diräsah Islämìyah.7

According to him, the main character of "Ulum al-Din (Religious Knowledge) is representing the "local tradition" of Islam based on "language" and the sacred religious texts (nass.s). The second's main character, namely al-Fiker al-Islami (Islamic thought) is representing the intellect-ratio-based humanity of Islamic thought. Meanwhile, the main character of Diräsah Islamiyah is presenting knowledge based on

\footnotetext{
5 Syamsun Ni'am, "Menimbang Kembali Pendekatan Kajian Keislaman di Perguruan Tinggi Agama Islam", al-Tahrir: Jurnal Pemikiran Islam, Vol. 11, No. 2 (2011), 364.

${ }^{6}$ Muhammad Azhar, "Metode Islamic Studies: Studi Komparatif antara Islamization of Knowledge dan Scientification of Islam," Jurnal Mukaddimah, Vol. 15, No. 26 (2009), 62.

7 Waryani Fajar Riyanto, Integrasi-Interkoneksi Keilmuan: Biografi Intelektual M. Amin Abdullab (1953-...): Person, Knowledge, and Institution (Bagian Pertama) (Yogyakarta: SUKA Press, 2013), 543.
} 
the critical-comparative approach under the social science paradigm within the diverse historical-empirical realm. ${ }^{8}$

Abdullah, also argued that for better Islamic studies, a linkage and interrelation between both 'Ulüm al-Din and Diräsah Islämìyah, despite enriching of each as well, through a mutual dialogical and complementary model. He said:

"The linkage and interrelation between the three, to my knowledge, are not hierarchical, where Ulüm al-Din has been assumed to have been the best, the highest, and the most important compared to the others. The relationship between the traditionalists (Ulüm al-Din) and the revisionist Islamic studies (Diräsah Islämìyah) does not lay in a relationship of a binary opposition which has its truth claims, negating the other contributions. The linkage between the three should be dialogical, complementary, and negotiate able".

The development of those three approaches in such Islamic studies signifies the existence of three kinds of epistemology, which refers to specific term conducted by Amin Abdullah called ḥadärah or civilization. Besides, he divided this hadärah into three classifications, namely ḥadārat al-nașs, hadārat al-falsafah, dan ḥad̄arat al-ilm. Hadàrat alnaș which is part of 'Ulūm al-Dīn is the sciences sourced from the sacred texts or revelations excavated through bayañ epistemology. As mentioned in the previous part, religious knowledge is consist of many discourses like theology, Islamic jurisprudence (fiqh), ethic (akhläq), Qur'ānic exegesis (tafsìr), hadīth, history (tärikhb) and language (lughah). In the Indonesian educational context, those discourses are classified as Islamic subjects.

Hadärat al-falsafah is a clump of al-Fikr al-Islämi science that is categorized as a logical-rational framework of thought. This hadärah has a reflective character that can bridge between hadärat al-naṣ dan hadàrat al-ilm. ${ }^{10}$ Considering its reflectivity, it is imaged as a wave frequency resonating then connecting that two other hadarah. The cluster of science classified into Hadärat al-falsafah is such philosophy, logic, theosophy, and mathematics. Kalam is classified into this

\footnotetext{
8 Ibid., 1086.

9 M. Amin Abdullah, "Islamic Studies in Higher Education in Indonesia Challenges, Impact and Prospects for the World Community," al-Jämi'ah: Journal of Islamic Studies, Vol. 55, No. 2 (2017), 391-426.

10 Riyanto, Integrasi, 1060.
} 
category as well considering that the usage of the rational-logical approach.

Meanwhile, Hadärat al-ilm is knowledge sourced from empirical approaches like sociology, anthropology, psychology, and the natural sciences. In this context, religion (Islam) and social or natural sciences are believed unlikely to contradict, but instead, the social and natural sciences can explain the doctrine of religion. The laws belong to nature are unlikely to contradict the laws contained in the Islamic sacred text (nasss).

In this regard, the presence of PTKI as an Islamic educational institution is carrying two missions, namely the mission of proselytism and science. The first mission means the college produces and distributes religious doctrine, values, and teachings to its academic members that are believed and practised as well. Meanwhile, the second mission aims to develop the knowledge in itself. Considering its trait, science is dynamic, changeable, and suable or even longlasting questionable, thus in this logic, indoctrination is irrelevant. Moreover, science is also open and consists of many possibilities of being understood differently.

Realizing that these science missions are obviously important and urging PTKI to have a greater contribution for the development of religion and science, and the state as well, despite that religious doctrines and teachings consistently being contextual (sälih li kull zamān wa makān) for its adherents, since the 1980s efforts have been made-using Dhofier's term-intellectualization of Islamic studies. Zamakhsyari Dhofier stated that since the early 1980s, there had been a shifting paradigm in understanding Islam, which further followed by significant changes in Islamic studies subject and approaches within Islamic higher educational institutions. ${ }^{11}$

Intellectualism within the PTKI environment is growing and well developed both normative and descriptive approaches, because most of PTKIN currently have well-organized. The curriculum presented already accommodates the use of branches of both. Especially in the context of IAIN Kediri, since the transformation of IAIN to be UIN, the use of both even is supported by the interconnected or integrative model. From this phenomenon, hence it is clear that the term integration-Islamization of science or "Islamic scientification" is no

11 Zamakhsyari Dhofier, "The Intellectualization of Islamic Studies in Indonesia", Indonesia Circle: School of Oriental and African Studies, Newsletter, 20:58, 20. 
longer new. Also, some research clusters under the Ministry of Religion and several PTKIN have urged, even required, an integrative model for its establishment.

As intellectualism in this environment grew and flourished, characterized by a large number of modern approaches usage, conservative turn yet was arising in the society-as stated by Martin Van Bruinessen. According to him, from 2005, the symptoms of conservative turn even began to encroach upon mainstream organizations in Indonesia, including Nahdlatul Ulama and Muhammadiyah. The modernist and liberal views were much more rejected by both organizations. The appearances of "conservative turn" indeed is frequently expressed by MUI through its fatwas (a non-binding religious statement declared by Islamic clerics in responding to a specific issue). Among hits conservative fatwas is declaring secularism, pluralism, and religious liberalism as incompatible and against Islam. ${ }^{12}$

The conservative term itself refers to a variety of expressions rejecting reinterpretation of Islamic teaching from a modernist, liberal or progressive perspective, yet leading to blindly following the established doctrines and social order that was long existed. For example, this attitude is well imaged through the refusal of gender equality view and hermeneutic approach in interpreting Qur'ān.13 Conservative turn trend was emerged because of various motivation. In the Indonesian context, one of those is the influx of Indonesian Muslim students who graduated from the Middle East, especially Saudi Arabia, who influenced by the new transnational Islamic movements doctrine. After their coming to Indonesia, those students immediately express and spread the conservative Islamic view among the society, which unfortunately they use freedom of expression under the democratic system to defend against those who disagree. ${ }^{14}$

\section{The Development of Study Materials and Approaches in Islamic Studies}

After analyzing the curriculum of the Faculty of Ushuluddin at IAIN Kediri since 1993 (while it still part of the IAIN Surabaya) until

\footnotetext{
12 Martin van Bruinessen, Contemporary Developments in Indonesian Islam: Explaining the Conservative Turn (Singapore: Institute of Southeast Asian Studies, 2013), 20.

${ }^{13}$ Ibid., 16.

${ }^{14}$ Ibid., 5.
} 
2016, it showed that there was a shifting model of the courses subject provided by the Faculty of Ushuluddin and Dakwah. To some extent, in 1993, the department of Comparative Religions (PA) provided many subjects on philosophical discourse. Meanwhile, during 20042013, the courses provided tended to focus more on socio-religious studies, and in 2016 this pattern growing to dominate the course model. Otherwise, this growing pattern reduced the number of credit units of the semester (SKS) of other subjects such as English and Arabic. During 1993 to 2013 period, both subject courses provided numerously different from the 2016 curriculum, which was reduced only to 4 credits. On the other hand, the course subject of tutoring for reading kitab kuning (literally means Yellow Book, Islamic literature written in Arabic) from 2004 until 2013 remained to exist, yet it was nothing within the 2016 curriculum. However, the tutoring course of reading Yellow Book surely is one of the hallmarks of classical Islamic studies and the reduction seems to be due to the addition of a course under the branches of hadarat al-ilm as mentioned above.

Likewise, the study program of Ilmu Alquran and Tafsir (IAT), previously Tafsir Hadis (TH), has several changes. However, this study program remains to preserve a large number of courses under qur'ānic exegeses and hadīth on each of its curriculum. In 2016, the curriculum of this study program cannot prevent reducing the number of credits on both courses comparing with those from 1993 until 2013. Nevertheless, through the 2016 curriculum integration course subject is provided, such as the courses of Islam and science, and the Qur'ān and Social Theory. These two courses seek to present an understanding of the Qur'ān with a new approach beyond hadàrat al-nass. Besides, the 2016 curriculum also offers many methods of interpretation to its students, ranging from Tafsir Mawdū $r$ then followed by presenting "Tafsir in the West," Classical and Contemporary Tafsir, as well as multimedia interpreters tailored to the needs of current students. Gender interpretation also become one of the presented course subjects in which it studies about male and female equality in the perspective of the Qur'ān. Others, Living Qur'ān and Hadīth Studies, are provided as well, which focuses is examining the phenomenon in implementing the Qur'ān and Hadìth among society within its daily life. The courses were in response to the development of science and the social changes in society. 
Formerly, the studies conducted especially in delivering religious teachings were dominantly taught on the normative-textual approach. Later on, in its further developments, through the policy requiring social sciences for being involved in the Faculty of Ushuluddin and Dakwah, the study of Islamic teachings was then coloured by a philosophical aspect. In this case, the Faculty of Ushuluddin and Dakwah-especially in IAIN Kediri and other similar faculties in common-began to organize Islamic studies emphasizing on empirical-historical approach; and nowadays sociological approach gradually has already taken part and coloured as well.

The curriculum made in this faculty continues to changes over time to seek an appropriate formulation to reinforce on actualizing integration and interconnection. The effort was found, for example, through student's final projects in which a socio-historical approach was increasingly widely used and no longer merely dominated by textual-doctoral (normative) approach. In the review conducted by Asror, there was a conclusion that "Ushuluddin's student studies STAIN Kediri, the department of Tafsir Hadis (now Ilmu Alquran and Tafsir/IAT) and Comparative Religions were not merely normative studies, but already many historical-empirical ones. This argument is emphasized by Asror through his finding that the final projects conducted by the students in IAT and religious studies mostly using a socio-historical perspective. Those students attempted to discuss among normative teaching of religion, social realities, and diversities within society. The students of IAT study program commonly use thematic exegesis approaches and responding the actual cases in the society as well as the students of religious studies who were not simply discussing theological aspects but also a socioreligious aspect. This increasing number of socio-historical and empirical trends of studies was the impact of the integration approach despite encouraging students to conduct field studies, including strengthening interdisciplinary methodology. ${ }^{15}$

\footnotetext{
15 Moh. Asror Yusuf, "Tema dan Pendekatan dalam Kajian Islam Mahasiswa Ushuluddin Kontemporer," Islamika: Jurnal Ilmu-imu Keislaman, Vol. 16, No. 2 (2016), 79-93.
} 


\section{Maintaining the Ideality of the Study Program in the Middle of Pragmatism}

Nowadays, people tend to be pervaded by a pragmatic mindset that seeing a truth based on material measurement. This fact consequently can defeat knowledge idealism, while prioritizing material matters. To some extent, materiality perhaps is seen as truth since it materially benefits and, more or less, educational institutions should adjust with this people's mindset. This presumption is proofed by the state regulation on accreditation of higher education ministry, mentioning that graduated students must be a competitive figure in work fields:

"A graduated student is an immediate result of a process or activity, or services measured using a particular measurement such as quality and relevance of graduates (GPA, study period, waiting for period of graduation, high quality for graduated one fits with work fields), research results, and community engagement". ${ }^{16}$

The demand to make relevant studies is not solely motivated for a good grade accreditation, but it also initiated by the stakeholder's order, particularly the external stakeholders that a PTKI can be welldeveloped. Since many of its alumni get a relevant job with its study program, the positive perceptions among the public toward a study program will increasingly high and immediately establishing high interest in society as well to join with the study program. Hence, this is how an increasing number of studies related to a work field matter for PTKI. In accordance, Islamic studies including the study program within the Faculty of Ushuluddin and Dakwah is facing the same issues. Those study program, on the one hand, remains to maintain its idealism to shape strong students character, having a high order of thinking and mastering scholarly or practically Islamic tenet. On the other hand, those study programs must deeply consider how to produces alumnus with a good skill which is related to the work fields.

Islamic Studies Program at PTKI (among others, the study of Religious Studies, the Qur'ān and Tafsìr, the Science of Hadìth, Sufism, and Psychotherapy) experienced the same thing. On the one hand, it should maintain the idealism of the vision and the mission of

\footnotetext{
${ }^{16}$ Badan Akreditasi Nasional Perguruan Tinggi (BAN-PT), Panduan Penyusunan LED (Laporan Evaluasi Diri) (Jakarta: BAN-PT, 2019), 3.
} 
the study program to form individuals who have character, able to have a high order of thinking and able to master and practice Islamic religious teachings. However, on the other hand, the study programs must strive to be able to meet the relevance demands of graduates with the work field. These study programs are challenged by the same demands as other study programs, such as sharia economics, sharia banking, and others for graduates to compete in the work field. The work field in this context refers to a kind of work with a certain basic wage.

The faculty of Ushuluddin is one of faculty department which delivers Islamic studies or to some extent the basic knowledge of Islam. In accordance, al-Ghāzali explained that the basic Islamic science consists of three main domain, theology, Islamic jurisprudence (figh), and theosophy. About the nomenclature of Islamic higher education under the Indonesian Ministry of Religious Affairs, theology and theosophy are put under the faculty of Ushuluddin, while Islamic jurisprudence (figh) is put under the faculty of Sharia.

The faculty of Ushuluddin in common has at least four main purposes; (1) it is charged to deliver basic Islamic tenets and to answer various existing problems mainly about faith in society. The faculty also has a mission to continuously explore and develop the understanding of Islamic teaching, especially, recoursed on the main Islamic literature, Qur'ān and Hadìth. (2) The faculty is charged to study, to understand, and to explain faith and behavioural aspect related to the existing views in the society. (3) The faculty is charged with delivering the Islamic ethic and its affection toward religion. It also studies and teaches the norms and individual behaviour toward God and His creation. On the other hand, the faculty also develop the studies of the mind, ethic, and behaviour of religious adherents. (4) Furthermore, this faculty takes a role to preach Islamic doctrine and its tenet toward the society that can be well understood. Also, it commonly also studies the existing preaching model to be developed then accommodated to the diverse societies

The field of science examined in this faculty is a fundamental of religious teaching aiming to develop religious science in society. Meanwhile, one of its goals is to produce expert scholars in the field of religious science. The doctrine and teachings of religion are delivered through textual review sourced from nass. (literature) of 
religion as well as historical aspect using philosophical, sociological, anthropological, and other approaches. Conceptual-theoretical studies practically are highly dominating in these faculties. Thus, it is no wonder that somehow the studies under the faculty tend to be philosophical, complex, and not easy to be understood, nor are they easy to be applied.

Based on those characters, it is understandable why the public, including prospective students, consider that studying in the faculty of Ushuluddin which much examines 'thought' within its complexity and they are presuming to have the ability in Arabic for understanding literature such as the Qur'ān, Hadìth, and tafsir. Most of them even assume that taking a program in this faculty is too heavy. This kind of presumption is a factor that makes prospective students reluctant to take this study.

Furthermore, in the context of IAIN Kediri and regarding the curriculum and approaches developed, the faculty of Ushuluddin aims to produce graduates student with complex thinking skills (higher order of thinking) that they can solve complex issues within religious people in the society. Hence, it expects its graduates to become a reliable figure in facing their different issues among society. HigherOrder of Thinking (HOT) is a mindset developed in the study programs under the faculty of Ushuluddin and Dakwah, specifically the Department of Religious Studies. It is a "high-level" thinking ability which means that students who have HOT competence will be able to explore the received knowledge or information and can connect with actual facts. Thus, they can interpret and analyze the information and finally making a decision for problem-solving.

A study on the importance of Higher Order of Thinking was long conducted by many scholars such as Bloom in 1956, Resnick in 1987, and Marzano in 1988 and 1992. "According to Bloom, HOT is an abstract ability in the cognitive realm of the objective education taxonomy. It includes analysis, synthesis, and evaluation. Meanwhile, according to Resnick, it is a process that is mentally involving, such as classification, induction, deduction, and reasoning. Adi W. Gunawan, in his book "Genius Learning Strategies" defines HOT as a strategy with a high-level thinking process, where students are encouraged to 
manipulate information and ideas in a particular way that provides them a new sense and implications. ${ }^{17}$

Realizing the importance of HOT, the education system in Malaysia even applies a high order of thinking to the student selfdevelopment. The Malaysian Ministry of Education (2013) defines HOTS as "the ability to apply knowledge, understanding, skills, and values in reasoning and reflecting in addition to solving problems, making decisions and producing innovations and other new things." Higher-order thinking is the type of thinking method that makes students can think creatively, critically, and innovatively to solve their problems with proper decisions. ${ }^{18}$

Based on the discussion above and seeing the perception of the society that certain job skills are a matter of importance for PTAI graduates, I argue that the development of higher-order of thinking is more important instead of merely equipping students with certain job skills. This argument does not intend to rule out certain job skills as less or not important competence. However, by further foregoing certain job skills alone and ignoring the development of higher-order thinking, I argue that it is an inappropriate decision considering that HOT offers students for having more complex skills.

\section{Developing Pesantren-Based Integrative Islamic Studies}

Since its inception, the Islamic Religious College (PTKI) has a great mission to integrate religious knowledge and science. This statement is emphasized by Muhammad Hatta's speech in the opening of Islamic Higher Education (Sekolah Tinggi Islam-STI) on April, $10^{\text {th }}$ 1946, in Yogyakarta. In his speech, Hatta stated that the purpose of STI was to produce Muslim scholars with a deep and wide understanding of religious knowledge while having dynamic motivation in academic nuance. Furthermore, he insisted that through this institution, religion and science will find its atmosphere of cooperation and lead the society to become prosperous. ${ }^{19}$

\footnotetext{
17 Anonim, "Kajian Teori Higher Order Thinking (HOT)," last modified 2019, accessed September 27, 2019, https://www.soalhots.com/2016/12/kajian-teorihigher-order-thinking-hot.html.

18 Norasmahani Zulkefli Aini and Khadijah Abdul Razak, "Generating HigherOrder Thinking Skills in Islamic Education through Information Communication Technology (ICT)," last modified 2018, accessed September 21, 2019, https://www.researchgate.net/profile/Zulkefli_Aini.

${ }^{19}$ Riyanto, Integrasi, 580.
} 
In accordance, there were many figures of Indonesian nation independence fighters such as Soekarno, Muhammad Hatta, Muhammad Natsir want that Muslim intellectuals born from Pesantren (Islamic boarding school) could develop their intellectuality, which it required integration of religious knowledge and other sciences within Islamic education. In this regard, Soekarno, even though he was more identified as a nationalist figure (not a religious one), once offered the integration of religious knowledge and natural science with so-called "Islam-science". Despite Soekarno's term on its notion, many other terms were used to describe integration such as the term "Religion and Science cooperation" belonged to Muhammad Hatta, kiai-intellect by Wahid Hasyim, Muslim clerics-intellect by Hamka and the last was Imtaq and Iptek by Habibie, the third president of Indonesia.

Seeing those terms initiated by the former Muslim stakeholders, the faculty of Ushuluddin and Dakwah of IAIN Kediri seems to adapt the Soekarno's for its mission as cited below "Excellent in the development of Islamic and social-religious knowledge based on the local wisdom and science at the national level in the year 2026." 20

Likewise, integration is a necessity so that the Islamic studies are available to be understood comprehensively and find its relevance to the life and needs of society. The attempt for integration motivated by the belief among Muslim society that Islam is a religion of mercy for all nature and will always comply with the demands of the contextual condition within different space and time (sälih li kull ramän wa makān) encourages Muslim intellectuals and Islamic higher education institution to continuously realize it. In this regard, the Faculty of Ushuluddin dan Dakwah of IAIN Kediri advocates for an integrated approach through the faculty's vision.

The main goal of integration and interconnection is to produce great Muslim scholars with comprehensive knowledge, openness who can dialogue and cooperate with other scholars, and thinking ahead. Those great scholars are expected to be able to contribute to solving a complex problem in terms of religion within society in this modern era. In this logic, integration is necessarily needed that Islamic knowledge can be understood contextually and further provide a contextual solution as well. In the establishment of integration,

20 "Profil Fakultas Ushuluddin Dan Dakwah," accessed July 14, 2019, http:// fuda.iainkediri.ac.id/. 
however, it is worth noticing that integration should not reduce, moreover eliminate, the basic substance and character of Islamic studies.

From a historical point of view, pesantren was recorded as the first institution along with its model in establishing Islamic education. Since the $19^{\text {th }}$ century, most Muslims have obtained religious education from this institution. Gradually, after the dependence of Indonesia along with the strong desire from the Muslim generation (santri, literally means Muslim students live in the pesantren) to be actively involved in building the nation, thus, many religious clerics initiated to conduct public education within pesantren which previously only deliver religious education. In further development, they also establish Islamic higher education (in its further development it is organized by the ministry of religious affairs under PTKI umbrella) that integration between Islamic knowledge and another subject can be well-worked.

In its early times, the curriculum and teaching model at PTKI was heavily dominated by religious science. The model of education previously was imitated the educational model belongs to al-Azhar University in Egypt, including for managing faculty division and curriculum. Nowadays, in PTKI, there are several faculties which its nomenclature is almost the same as al-Azhar University. The Faculty of Ushuluddin and Dakwah of al-Azhar University major programs are including (1) Theology and Philosophy, (2) Qur'ān and Ulum Tafsir, (3) Hadis and Ulumul Hadis, (4) Dakwah and Islamic Culture, (5) Comparative Religion and School of Thought, (6) Islamic Culture, (7) Islamic Mass Communication. ${ }^{21}$ From those data, it is clear that the nomenclature of these study programs in this faculty is similar to the study programs of similar faculty in IAIN in Indonesia, including IAIN Kediri.

Since the religious education in Indonesia is a pesantren, it is not an exaggeration to conclude that the early embryos of Islamic higher education are pesantren, ${ }^{22}$ besides the fact that the founding figures of the PTKI are coming from pesantren. In realizing this, the education of pesantren has had strong roots in Indonesia long before the era of

21 Tim Ditjen Pendis, Model Pengembangan Pendidikan Tinggi: Pengalaman dari Mesir, Singapura, Jerman, dan Australia (Jakarta: Ditjen Pendis, 2011), 97.

22 Riyanto, Integrasi, 542. 
independence. When the colonial era came in the $19^{\text {th }}$ century, the education of pesantren has further developed.

.Therefore, the intellectualization, integration, or other terms used to describe the model of Islamic Studies involving other disciplines (general sciences) should be based on the principles and values contained in the Islamic study patterns applied in pesantren. The principles and values of the pesantren need to be developed in this faculty. Thus, it is expected that this faculty or the Islamic universities, in general, can still run the mission of preaching as well as an intellectual mission for the development of science.

The Faculty of Ushuluddin and Dakwah at IAIN Kediri are located in the area of pesantren milieu, so that many stakeholders are coming from "pesantren community." If we pay attention to the stakeholders, the Faculty of Ushuluddin and Dakwah should explore the principles and culture of pesantren-based education as a cornerstone in the scientific development of this faculty. In this context, "the local wisdom-based" can be interpreted as an effort to develop Islamic knowledge with a modern approach (read: intellectualization) while maintaining the principles and values of the education system of pesantren. Since around a century ago, pesantren has been living and colouring the traditions of Kediri and surrounding communities. Hence, it can be said that the local wisdom of Kediri much more influenced by pesantren. For example, the Pesantren Lirboyo in Kediri, which has many influences on the religious and social dynamics of Kediri and surrounding communities, has established since 1910.

By developing the values of pesantren in Islamic studies, the faculty will be able to answer the needs of the community, especially those who experience the "conservative turn". In line with the need to respond to "conservative turn," it is not enough to only develop intellectualization and integration, but it is also essential to strengthen student's ability to study the religious text (nass). Some students and alumni still propose the strengthening of 'hadärat al-nass?' capability, which includes courses to form student's ability to understand the "Yellow Book" (book in Arabic script used in pesantren milieu). ${ }^{23}$

23 See more detail in Martin van Bruinessen, "Kitab Kuning: Books in Arabic Script Used in the Pesantren Milieu; Comments on a New Collection in the KITLV Library", Journal of the Humanities and Social Sciences of Southeast Asia, Vol. 146, No. 2 (1990), 226-269. 
Some students and alumni feel that there is a need to put the study of Arabic as an equally important subject as others because they realize that to deepen the knowledge of Islam or religious studies, they must possess the original language, which is Arabic.

In this regard, the study of Islamic studies in universities should continue to use Arabic. Some reasons are as follows: (1) The Arabic language is often used by every Muslim, although it is only spoken language without a proper understanding of meaning. The example includes the call to prayer (azan), Islamic creed (shahadab), prayer, reading the Qur'ān, and so on (2) the Islamic literature including the Qur'àn, Tafsir, Hadīth, Sharḅ al-Hadith, Fiqh, Ușül al-Fiqh, the Prophet's Sirah, all are in Arabic. Indeed, these books have been widely translated, but it must be realized that this translation cannot always represent the original meaning of the book.

If the use of the Arabic language in the learning process cannot be optimized, the access to "Yellow Book" as the primary references, such as the book of Tafsir, cannot also be maximized. This makes the study of 'hadärat al-nass?' not possible. Consequently, it is difficult to connect the study of 'ḅadarat al-ilm with the study of 'ḅadarat al-nass'. Hence, it is necessary to highly consider the learning of Arabic, including 'Ulüm al-Qur'an, Balaghbah, and others which function as a "tools" to understand Arabic-speaking references.

There is a view that teaching science is considered to be more effective when using the local or national language of students and lecturers. In this context, the material presented by lecturers will be easier to understand. In Islamic Studies, materials may be easier to understand if using its local or national language. However, whether the teaching using translated material is the same compared to the teaching that uses the source is still more to be studied. ${ }^{24}$ Nevertheless, the development of the Arabic language needs attention for students to be able to master hadärat al-nașs before integrating or interconnecting it with hadärat al-ilm.

\section{Developing Islamic Studies with Practical Theology Approach}

The effort to integrate between religious and social sciences is very important, not only in the framework of scientific development but also in the context of developing student attitudes and behaviour.

${ }^{24}$ Imtiaz Ahmad, "Teaching Islamic Studies in the Non-Arab World: With or Without Arabic?," Journal of Muslim Minority Affairs, Vol. 21, No. 2 (2001). 
In other words, the development of rationality and scientific stance needs to be integrated with the development of religiosity.

Essentially, human beings consist of three parts; the body, the mind, and the spirit. All three must be integrated at each level in order to create balance and perfection. However, they should be empowered in a balanced manner according to their functions, with no disruption to other functions. On the other hand, although it seems to have its own "objectivity", it does not mean that it cannot be integrated. As Sayyed Hossein Nasr stated that "although the body is the outermost aspect of humans, which has its existence and way of its actions, this is not the biggest obstacle for integration efforts." 25

In the scope of education at PTKI, these three parts of human beings need to be integrated to actualize the students with good character. The development of the body should not be separated from the building of the mind. Similarly, the development of the mind must also be in line with the soul because it is a form of hierarchy that cannot be separated from the centre of existence (read: God). Generally, in this modern era, the development of the body often ignores the development of the mind and the existence of the human soul in which it often leads to inequality in humans. This gradually makes modern humans more likely to lose their meaning and purpose of life. They began to be "exiled" or "alienated" from their natural environment, the community, and even from themselves as well. In the end, it will lead to the loss of harmony, both concerning the self, to nature, and God. ${ }^{26}$ Other impacts that potentially arise from the loss of harmony are corruption, pragmatism, hedonism, and adolescent delinquency that are increasingly symptomatic in many places.

In line with that, the purpose of education is to develop and integrate all three important parts of human beings, namely the body, the mind and the soul on the purpose of national education. In the constitution, no. 20 of 2003 chapter II of article 3, it is mentioned that "The National Education functions to develop the capability, character, and civilization of the nation for enhancing its intellectual capacity, and is aimed at developing students potentials so that they become persons imbued with human values which are faithful and

\footnotetext{
${ }^{25}$ Seyyed Hossein Nasr, Living Sufism (London: Mandala Books, 1980), 32.

${ }^{26}$ Budhy Munawar-Rahman, Islam Pluralis: Wacana Kesetaraan Kaum Beriman (Jakarta: Paramadina, 2001), 102.
} 
pious to one and only God; who possess morals and noble character; who are healthy, knowledgeable, competent, creative, independent; and as citizens are democratic and responsible."

Religious education has been positioned as a major aspect of building religiosity and good morality. Religious people believe that the religion originating from the revelations of God has a high commitment to establishing noble morality. Through the noble values in it, religion is believed to have the power to build religious consciousness as well as to develop positive qualities in a person. Based on such beliefs, religious education has a special position in the national education system. The act of law No. 20 of 2003 Article 12 paragraph 1a explains that each student in each education unit is entitled to receive religious education in accordance with the religion it professes and is taught by educators of the same religion. ${ }^{27}$

The self-development of the student should be done comprehensively; this is because education is very influential in the future of an individual's life. Development of student personality while studying goes hand in hand with the development of academic achievement. ${ }^{28}$ According to Alatas, education is important to lead towards the cultivation of the intellect and humanity as a whole. Students, as leaders of the future, must be educated to think critically and rationally so that the establishment of a civil society based on intellectuality and human rights can be realized. In addition, the purpose of education, in general, is to build thorough thinking, mind and personality, not merely the process of obtaining a diploma. ${ }^{29}$

In the context of religious-based education, PTKI remains the focus of society in shaping the religious identity of the younger generation. Indonesian society, as a religious society, believes that religion teaches intact doctrines in its efforts to produces a noble human character. Religions are believed to have the power to build religious consciousness as well as to develop positive character in a

\footnotetext{
27 Bagus Mustakim, Pendidikan Karakter, Membangun Delapan Karakter Emas Menuju Indonesia Bermartabat (Yogyakarta: Samudra Biru, 2011), 51.

28 Mohd. Fadzilah Kamsah, "Perubahan Bersepadu Menjana Mahasiswa yang Cemerlang," in Abdul Razaq Ahmad (ed.), Mabasiswa Abad 21 (Malaysia: Fakulti Pendidikan Universitas Kebangsaan Malaysia, 2005), 47.

${ }^{29}$ Syed Hussein Alatas, "Pemikiran dan Falsafah Pendidikan: Mahasiswa Abad 21," in Mabasiswa Abad 21, ed. Abdul Razaq Ahmad (Malaysia: Fakulti Pendidikan Universitas Kebangsaan Malaysia, 2005), 37.
} 
person. Therefore, religious education gained special attention in the national education system. ${ }^{30}$

On the other hand, as an ideology, one of the religious functions is to legitimize an action. However, this function is very vulnerable to use by certain individuals or groups for the sake of domination. ${ }^{31}$ Therefore, it takes an Islamic study that can provide a comprehensive understanding to regulate the religious quality of a person.

Islamic studies developed in the world of education should ideally prioritize andragogical aspects. Andragogical principles are very synergistic with the development of self-reliance learning from a learner. Andragogical learning process should consider the needs of learners as well as some aspects of individuality as uniqueness and potential that must be developed. ${ }^{32}$ Islamic studies should be able to increase the religious commitment of students from both aspects of belief and practice. Besides, it also has to emphasize the efforts of self-development by presenting relevant teaching materials both in theory and practice. Thus, the religious knowledge and experience presented to the student are expected to deepen their knowledge and to make them able to respond to their respective circumstances. ${ }^{33}$

In this regard, Veerasamy explained that religious identity is formed through six stages of status, namely: (1) concrete, (2) relational, (3) confusion, (4) cognitive-rationalization, (5) exploration, and (6) acceptance. First, concrete status is characterized by the obedient feelings demonstrated by practising religion, rigid and uncompromising behaviour, self-defence attitudes and right-feeling, and religious understanding that relies on the view of authority. Secondly, in a relational status, individuals tend to do logical deeds, although they are still limited to what makes sense to others. Thirdly, in the confusion status, the individual is distinguished into two characters seen from the attitude, whether one feels anxiousexpressed by anger-because of the betrayal of others against one's

\footnotetext{
30 Mustakim, Pendidikan Karakter, 51.

${ }^{31}$ Limas Dodi, "Ideologi Agama dalam Praktik Dominasi antara LDII Versus NonLDII Di Jombang," Teosofi: Jurnal Tasawuf dan Pemikiran Islam, Vol. 8, No. 1 (2018), 191-217.

32 Sufirmansyah, "Actualization of Andragogical Learning Strategies for Higher Education in Disruption Era," Didaktika Religia, Vol. 6, No. 2 (2018), 351-370.

33 Inkeri Rissanen, "Developing Religious Identities of Muslim Students in the Classroom: A Case Study from Finland," British Journal of Religious Education, Vol. 36, No. 2 (2014), 123-138.
} 
religion; or whether one allowed others to define their religion. Fourth, cognitive-rationalization status explains that individuals interpret religion intellectually and reject any illogical understanding. Fifth, individuals in the status of exploration make a serious effort to obtain the meaning and essence of true religion and are pleased to review alternative views or understandings. Sixth, the individual in the acceptance status feels comfortable with their religion. They do not feel that there is a psychological rejection on them and sincerely accept and appreciates other religions. ${ }^{34}$ From these stages, I saw that no 1 to 3 stages should be developed at the school level, and the rest, which is stage 4 to 6 should be applied in higher education.

Seen from the above perspective, the Islamic studies presented in the lecture should not only be limited to the aspect of knowledge but also has to develop students' religious practice. It cannot be merely the submission of doctrines and beliefs but should also emphasize the implementation or praxis of that belief. This means that the religious education provided in the institution should not only be oriented towards intellectual exercise, but also on the development aspects of religious behaviour. If this is done, the assessment will be more useful and suitable for the needs of students and society.

With this model, students are expected to have not only sufficient religious understanding but also able to get used to carrying out religious practices in daily life. This model emerged because of the realization that the religious identity of a person is formed through a life process and different religious expressions-which then demands the ability to adapt and change themselves-in response to a variety of experiences, relationships, and cultural settings in social relations. ${ }^{35}$ As such, a person's religious identity is something that develops and can experience change over time. Identity is the result of a person's construction on the knowledge and experience of living in the environment so that each individual can certainly have a different experience during the process of establishing their religious identity. ${ }^{36}$

34 Tevni E. Grajales and Brittany Sommers, "Identity Styles and Religiosity: Examining the Role of Identity Commitment", Journal of Research on Christian Education, Vol. 25, No. 2 (2016), 188-202.

35 Meredith B. McGuire, Lived Religion, Faith and Practice in Everyday Life (New York: Oxford University Press, 2008), 209.

36 Robert J. Thompson, "Identity and the Process of Self-Authorship," in Beyond Reason and Tolerance: The Purpose and Practice of Higher Education (Oxford: Oxford Scholarship, 2014). 
This argument is parallel with McGuire's statement that the definition of commitment and religious identity exists in the contestation, shifting, and not rigid spaces. ${ }^{37}$

In this context, I argue that Islamic studies need to implement a practical theology approach in which it can be accomplished by taking four steps as follows:

1. The-descriptive-empirical task. Compiling information that helps us understand patterns and dynamics in certain situations, conditions, and contexts.

2. The interpretative task. Examine the theory of art and science to understand the pattern and dynamics that occur.

3. The normative task. Using theological concepts to interpret certain situations, conditions, and contexts, and constructs ethical norms as a guideline in responding to these conditions, and learning from "good practice."

4. The pragmatic task. The final step is determining the necessary action strategies that will affect the situation, and perform reflections through the "talk back" that appears when the strategy is implemented. 38

From the main discussion of this research, I concluded that the integration of religious knowledge with social and natural science is important to find the relevance of theological doctrine to the actual needs of the society. The practical theology approach can be part of the implementation of the integration of Islamic scholarship in response to humanitarian issues. In this case, the faculty of Ushuluddin and Dakwah of IAIN Kediri need to reinforce the commitment and actualize the real implementation in the theological examination both with the integrative and praxis approach.

\section{Concluding Remarks}

The Faculty of Ushuluddin and Dakwah at the State Institute of Islamic Studies Kediri must respond to the various challenges that exist to continue the ideals of founding fathers and answer stakeholder's hesitation about the quality of their graduates. This can be done through the concept of integration with a "practical theology" approach so that the scientific field studied by students will always be

\footnotetext{
${ }^{37}$ McGuire, Lived Religion, 187.

38 Richard R. Osmer, Practical Theology: An Introduction (Michigan: Wm.B. Eerdmans Publishing, 2008), 4.
} 
able to find its relevance to the needs of society. Likewise, Higher Order Thinking competence should be continuously implemented to the teaching model because it examines the student to have complex skills. On the other hand, strengthening hadarat al-nass is necessarily needed and the faculty should give needs special attention to primary literature such as the "Yellow Book" to be used as an important reference in Islamic Studies. In this context, the model of integrated Islamic studies based on pesantren might become an alternative solution because it seems to be able to support students' ability to master religious literature, specifically, in Arabic, such as the "Yellow Book".

\section{Bibliography}

"Profil Fakultas Ushuluddin dan Dakwah," accessed July 14, 2019, http:/ / fuda.iainkediri.ac.id.

A Report to HEFCE, International Approaches to Islamic Studies in Higher Education, Subject Centre for Languages, Linguistics and Area Studies, Subject Centre for Philosophical and Religious Studies, June 2008.

Abdullah, M. Amin. "Islamic Studies in Higher Education in Indonesia Challenges, Impact and Prospects for the World Community," alJami'ab: Journal of Islamic Studies, Vol. 55, No. 2, 2017.

Ahmad, Imtiaz. "Teaching Islamic Studies in the Non-Arab World: With or Without Arabic?," Journal of Muslim Minority Affairs, Vol. 21, No. 2, 2001.

Aini, Norasmahani Zulkefli and Razak, Khadijah Abdul. "Generating Higher-Order Thinking Skills in Islamic Education through Information Communication Technology (ICT)," last modified 2018, accessed September 21, 2019, https://www.researchgate.net/profile/Zulkefli_Aini.

Alatas, Syed Hussein. "Pemikiran dan Falsafah Pendidikan: Mahasiswa Abad 21," in Mahasiswa Abad 21, ed. Abdul Razaq Ahmad. Malaysia: Fakulti Pendidikan Universitas Kebangsaan Malaysia, 2005.

Anonim. "Kajian Teori Higher Order Thinking (HOT)," last modified 2019, accessed September 27, 2019, https://www.soalhots.com/2016/12/kajian-teori-higher-orderthinking-hot.html. 
Azhar, Muhammad. "Metode Islamic Studies: Studi Komparatif antara Islamization of Knowledge dan Scientification of Islam," Jurnal Mukaddimah, Vol. 15, No. 26, 2009.

Badan Akreditasi Nasional Perguruan Tinggi (BAN-PT), Panduan Penyusunan LED (Laporan Evaluasi Diri). Jakarta: BAN-PT, 2019.

Bakar, Osman. Hierarki Ilmu: Membangun Rangka Pikir Islamisasi Ilmu, terj. Purwanto. Bandung: Mizan, 1992.

Bruinessen, Martin van. "Kitab Kuning: Books in Arabic Script Used in the Pesantren Milieu; Comments on a New Collection in the KITLV Library", Journal of the Humanities and Social Sciences of Southeast Asia, Vol. 146, No. 2, 1990.

----. Contemporary Developments in Indonesian Islam: Explaining the Conservative Turn. Singapore: Institute of Southeast Asian Studies, 2013.

Dhofier, Zamakhsyari. "The Intellectualization of Islamic Studies in Indonesia", Indonesia Circle: School of Oriental and African Studies, Newsletter, 20:58.

Ditjen Pendis, Tim. Model Pengembangan Pendidikan Tinggi: Pengalaman dari Mesir, Singapura, Jerman, dan Australia. Jakarta: Ditjen Pendis, 2011.

Dodi, Limas. "Ideologi Agama dalam Praktik Dominasi antara LDII Versus Non-LDII Di Jombang," Teosofi: Jurnal Tasawnf dan Pemikiran Islam, Vol. 8, No. 1, 2018.

Grajales, Tevni E. and Sommers, Brittany. "Identity Styles and Religiosity: Examining the Role of Identity Commitment", Journal of Research on Christian Education, Vol. 25, No. 2, 2016.

Jaiz, Hartono Ahmad. Ada Pemurtadan di LAIN. Jakarta: Pustaka alKautsar, 2004.

Kamsah, Mohd. Fadzilah. "Perubahan Bersepadu Menjana Mahasiswa yang Cemerlang," in Abdul Razaq Ahmad (ed.), Mahasiswa Abad 21. Malaysia: Fakulti Pendidikan Universitas Kebangsaan Malaysia, 2005.

Machasin dkk. "Strategi Peningkatan Mutu Perguruan Tinggi Agama Islam Berbasis Balanced Scorecard," Walisongo, Vol. 19, No. 2, 2011.

McGuire, Meredith B. Lived Religion, Faith and Practice in Everyday Life. New York: Oxford University Press, 2008.

Munawar-Rahman, Budhy. Islam Pluralis: Wacana Kesetaraan Kaum Beriman. Jakarta: Paramadina, 2001. 
Mustakim, Bagus. Pendidikan Karakter, Membangun Delapan Karakter Emas Menuju Indonesia Bermartabat. Yogyakarta: Samudra Biru, 2011.

Nasr, Seyyed Hossein. Living Sufism. London: Mandala Books, 1980.

Ni'am, Syamsun. "Menimbang Kembali Pendekatan Kajian Keislaman di Perguruan Tinggi Agama Islam", al-Tabrir: Jurnal Pemikiran Islam, Vol. 11, No. 2, 2011.

Osmer, Richard R. Practical Theology: An Introduction. Michigan: Wm.B. Eerdmans Publishing, 2008.

Rissanen, Inkeri. "Developing Religious Identities of Muslim Students in the Classroom: A Case Study from Finland," British Journal of Religious Education, Vol. 36, No. 2, 2014.

Riyanto, Waryani Fajar. Integrasi-Interkoneksi Keilmuan: Biografi Intelektual M. Amin Abdullah (1953-...): Person, Knowledge, and Institution (Bagian Pertama). Yogyakarta: SUKA Press, 2013.

Thompson, Robert J. "Identity and the Process of Self-Authorship," in Beyond Reason and Tolerance: The Purpose and Practice of Higher Education. Oxford: Oxford Scholarship, 2014.

Sufirmansyah. "Actualization of Andragogical Learning Strategies for Higher Education in Disruption Era," Didaktika Religia, Vol. 6, No. 2, 2018.

Yusuf, Moh. Asror. "Tema dan Pendekatan dalam Kajian Islam Mahasiswa Ushuluddin Kontemporer," Islamika: Jurnal Ilmu-ilmu Keislaman, Vol. 16, No. 2, 2016. 